Article

\title{
Chemoinformatic Analysis of Selected Cacalolides from Psacalium decompositum (A. Gray) H. Rob. \& Brettell and Psacalium peltatum (Kunth) Cass. and Their Effects on FceRI-Dependent Degranulation in Mast Cells
}

\author{
Jorge Iván Castillo-Arellano ${ }^{1,2,+}$, Juan Carlos Gómez-Verjan ${ }^{3,+}$, Nadia A. Rojano-Vilchis ${ }^{2}$, \\ Myrna Mendoza-Cruz ${ }^{4}$, Manuel Jiménez-Estrada ${ }^{2}$, Héctor E. López-Valdés ${ }^{5}$, \\ Hilda Martínez-Coria ${ }^{5}$, Roger Gutiérrez-Juárez ${ }^{6}$, Claudia González-Espinosa ${ }^{1, *(D)}$, \\ Ricardo Reyes-Chilpa ${ }^{2, *}$ and Isabel Arrieta-Cruz ${ }^{3, *}$ \\ 1 Pharmacobiology Department, Center for Research and Advanced Studies of the National Polytechnic \\ Institute, Mexico City 14330, Mexico; jorge.ivan@ciencias.unam.mx \\ 2 Department of Natural Products, Institute of Chemistry, National Autonomous University of Mexico, \\ Mexico City 04510, Mexico; nadiarojano@yahoo.com.mx (N.A.R.-V.); manuelj@unam.mx (M.J.-E.) \\ 3 Department of Basic Research, National Institute of Geriatrics, Ministry of Health, Mexico City 10200, \\ Mexico; carlosverjan132@gmail.com \\ 4 Botanical Garden, Institute of Biology, National Autonomous University of Mexico, Mexico City 04510, \\ Mexico; myrna@ib.unam.mx \\ 5 Division of Research, Faculty of Medicine, National Autonomous University of Mexico, Mexico City 04510, \\ Mexico; helopezv@gmail.com (H.E.L.-V.); hildamcoria@gmail.com (H.M.-C.) \\ 6 Department of Biomedical Sciences, Faculty of High Studies Zaragoza, National Autonomous University of \\ Mexico, Mexico City 09230, Mexico; roger.gutierrez@zaragoza.unam.mx \\ * Correspondence: cgonzal@cinvestav.mx (C.G.-E.); chilpa@unam.mx (R.R.-C.); arrieta777@mail.com (I.A.-C.); \\ Tel.: +52-55-54832875 (C.G.-E.); +52-55-56224512 (R.R.-C.); +52-55-56551921 (I.A.-C.) \\ + These authors contributed equally to this work.
}

Academic Editor: Alessandra Guerrini

Received: 6 November 2018; Accepted: 15 December 2018; Published: 19 December 2018

\begin{abstract}
Cacalolides are a kind of sesquiterpenoids natural compounds synthesized by Psacalium decompositum (A. Gray) H. Rob. \& Brettell or Psacalium peltatum (Kunth) Cass. Antioxidant and hypoglycemic effects have been found for cacalolides such as cacalol, cacalone or maturine, however, their effects on inflammatory processes are still largely unclear. The main aim of this study was to investigate the biological activities of secondary metabolites from $P$. decompositum and $P$. peltatum through two approaches: (1) chemoinformatic and toxicoinformatic analysis based on ethnopharmacologic background; and (2) the evaluation of their potential anti-inflammatory/anti-allergic effects in bone marrow-derived mast cells by IgE/antigen complexes. The bioinformatics properties of the compounds: cacalol; cacalone; cacalol acetate and maturin acetate were evaluated through Osiris DataWarrior software and Molinspiration and PROTOX server. In vitro studies were performed to test the ability of these four compounds to inhibit antigen-dependent degranulation and intracellular calcium mobilization, as well as the production of reactive oxygen species in bone marrow-derived mast cells. Our findings showed that cacalol displayed better bioinformatics properties, also exhibited a potent inhibitory activity on $\operatorname{IgE}$ /antigen-dependent degranulation and significantly reduced the intracellular calcium mobilization on mast cells. These data suggested that cacalol could reduce the negative effects of the mast cell-dependent inflammatory process.
\end{abstract}

Keywords: Psacalium decompositum; Psacalium peltatum; cacalol; calcium channels; maturin; reactive oxygen species; inflammation 


\section{Introduction}

Mast cells are key effectors of type I hypersensitivity reactions (allergies) and other inflammatory reactions, since they secrete numerous pre-formed and de novo synthesized pro-inflammatory mediators that promote endothelial activation, smooth muscle contraction and chemotaxis of other immune cells to the site where mast cells are activated [1]. Allergic inflammation differs from other innate inflammatory reactions in that the first are intense, rapid, and can lead to complex life-threatening conditions such as asthma and anaphylaxis [2]. The main mechanism of mast cells activation in allergy is the crosslinking of the high affinity immunoglobulin E (IgE) receptor (FceRI) with IgE/antigen (IgE/Ag) complexes. FceRI signal transduction requires the production of reactive oxygen species (ROS) and calcium mobilization, together with the activation of selected kinases to trigger degranulation and the consequent release of histamine, $\beta$-hexosaminidase, serotonin and tumor necrosis factor (TNF), in addition to the de novo production of prostaglandins, leukotrienes and numerous cytokines [3]. IgE/Ag-dependent degranulation and cytokine synthesis of mast cells have been recognized as relevant pharmacological targets for the control of allergic reactions [4]. However, despite the importance of allergic diseases worldwide, appropriate pharmacological control of mast cells degranulation has not been achieved yet [5]. The FcERI-dependent degranulation in mast cells is an appropriate model to study the effects of new natural products on inflammation. In fact, some natural compounds have been tested in models of mast cells-dependent inflammation; for example, we have recently described that the xanthone jacareubin, a natural product from the tropical tree Calophyllum brasiliense displays potent anti-allergic and anti-inflammatory activities in degranulation of mouse mast cells [6].

On the other hand, Psacalium decompositum (A. Gray) H. Rob. \& Brettell, belonging from Asteraceae family is a wild herb from the pine forests of Northwest Mexico, commonly known as "matarique" and used locally as a remedy in folk medicine. The Raramuri people and peasants of the State of Chihuahua, use a decoction of the roots and rhizome of this species for the treatment of rheumatic disorders, pain, hepatic and renal colic, neuralgia, ulcers and colds. The roots and rhizome contain a number of sesquiterpenoids cacalolides such as cacalol, cacalone, epicacalone, maturine, 3-hydroxycacalolide, epi-3-hydroxycacalolide [7-9]. Additionally, P. decompositum is currently used by the urban populations of Mexico as an antidiabetic remedy; in fact, several studies have examined the hypoglycemic properties of cacalol and other cacalolides [8]. Interestingly, the decoction of the roots from $P$. decompositum has shown clear hypoglycemic effects in healthy mice and in transtiently hyperglycemic rabbits [7]. Besides, polysaccharide fractions obtained from the freeze-dried water extract from $P$. decompositum significantly reduced fasting blood glucose in mild alloxan-diabetic mice suggesting that the aqueous fraction, containing fructan-type oligosaccharides, is responsible for the hypoglycemic effects observed $[8,10]$. Recently, treatment with a fructooligosaccharides fraction from $P$. decompositum was shown to significantly reduce cholesterol, triglycerides, IL-6, IFN- $\gamma$, MCP-1, IL-1 $\beta$ and VEGF levels, as well as a decrease in body weight in an animal model of obesity. These observations suggest novel anti-inflammatory and hypolipidemic properties of the fructooligosaccharides fraction [11]. Meanwhile, the hexane extract and two compounds, cacalol and cacalone isolated from $P$. decompositum, have been shown to inhibit inflammation in the carrageenan-induced edema of the rat paw; these compounds also exhibited a dose-dependent anti-inflammatory activity in the TPA-induced mouse ear edema. In these models cacalone had the most prominent activity [12].

In medicinal plant markets of Mexico City, Psacalium peltatum (Kunth) Cass., is a common substitute for P. decompositum, because the former grows in the nearby pine forests. P. peltatum is also kown as "matarique" and the roots and rhizome also contain cacalolides, such as maturin, maturin acetate, and maturinin, but not cacalol or cacalone. Few studies have shown the potential effects of maturine acetate in the inflammatory process; maturine acetate reduces the production of pro-inflammatory cytokines (TNF- $\alpha$ and IL-1 $\beta$ ) by lypopolysaccharide (LPS)-activated peritoneal macrophages. Maturine acetate also stimulates the proliferation of murine macrophages and 
splenocytes, induces lysosomal enzyme activity, pinocytosis and NK cell activity, as well as increases the release of IL-2, IL-15 and IFN- $\gamma$ in immunosuppressed mice, showing relevant immunostimulatory activities $[13,14]$.

Despite all the available literature, there is currently no information about the physicochemical, pharmacokinetic, medicinal chemistry and toxicoinformatic properties of some cacalolides. Thus, we aimed to examine the biological activities of secondary metabolites from P. decompositum and P. peltatum through two not mutually exclusive approaches: (1) bioinformatic analysis: chemoinformatic and toxicoinformatic; and (2) pharmacological investigations based on ethnomedical use.

Chemoinformatic and toxicoinformatic have demonstrated to be reasonable alternatives for the early estimation of absorption, distribution, metabolism, excretion and toxicity (ADMET) properties and represent substantial time and cost reductions during the drug discovery phase [15]. This is the reason why in recent years several groups have used this type of computational methodologies to improve and accelerate drug design.

With the aim of providing detailed information about of the compounds, in this work we performed a chemoinformatic and toxicoinformatic analysis of four cacalolides: cacalol, cacalol acetate, cacalone and maturin acetate isolated from P. decompositum and P. peltatum. Besides, we described a potential anti-inflammatory/anti-allergic activity of these compounds on mast cells not previously reported. Furthermore, we postulate a possible molecular mechanism for the inhibition of inflammation by these compounds.

\section{Results}

\subsection{Chemoinformatic and Toxicoinformatic Analysis of Cacalolides from P. decompositum and P. peltatum}

The bioinformatic properties of the cacalolides: cacalol, cacalone, cacalol acetate and maturin acetate (Figure 1) were examined. Among all cacalolides only cacalol displayed high water solubility conferring it some advantages such as a good drug gastrointestinal absorption and adequate blood-brain barrier penetration. According to Lipinski, Ghose and Lead-likenes classification, cacalol had the best score regarding bioavailability, biosynthesis and pharmacokinetics. Interestingly, all studied cacalolides exhibited a very low toxicity and in no case mutagenic or tumorigenic effects were detected (Table 1).
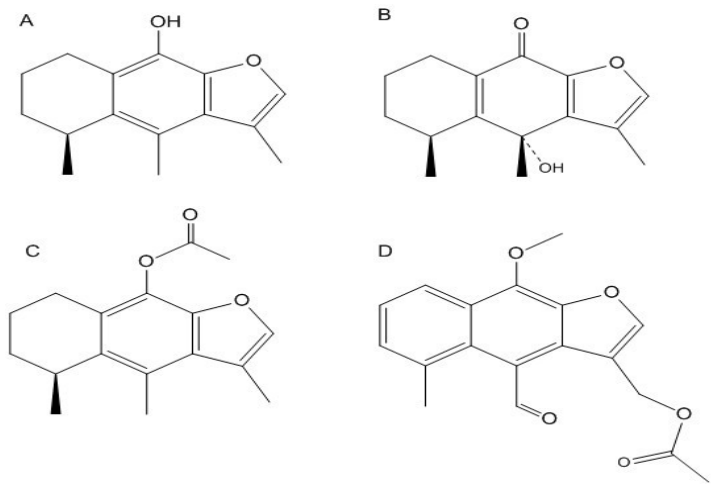

Figure 1. Chemical structures of cacalolides from two species of matarique ( $P$. decompositum and $P$. peltatum): (A) cacalol; (B) cacalone; (C) cacalol acetate; (D) maturin acetate. 
Table 1. Estimated physicochemical, pharmacokinetic, medicinal chemistry and toxicoinformatic properties of cacalolides *.

\begin{tabular}{|c|c|c|c|c|c|}
\hline & & Cacalol & Cacalone & $\begin{array}{l}\text { Cacalol } \\
\text { Acetate }\end{array}$ & Maturin Acetate \\
\hline \multirow{8}{*}{$\begin{array}{l}\text { Physicochemical } \\
\text { Properties }\end{array}$} & $\log P$ & 3.65 & 2.56 & 3.42 & 3.20 \\
\hline & $\log S$ & -5.56 & -4.04 & -4.34 & -5.09 \\
\hline & TPSA & $33.37 \mathrm{~A}$ & $50.44 \mathrm{~A}$ & $39.44 \mathrm{~A}$ & $65.74 \mathrm{~A}$ \\
\hline & MW & $230.30 \mathrm{~g} / \mathrm{mol}$ & $246.30 \mathrm{~g} / \mathrm{mol}$ & $272.34 \mathrm{~g} / \mathrm{mol}$ & $312.34 \mathrm{~g} / \mathrm{mol}$ \\
\hline & $\mathrm{RB}$ & 0 & 0 & 2 & 5 \\
\hline & $\mathrm{BD}$ & 1 & 1 & 0 & 0 \\
\hline & BA & 2 & 3 & 3 & 5 \\
\hline & $\begin{array}{l}\text { Molar } \\
\text { refractivity }\end{array}$ & 70.64 & 68.83 & 78.26 & 86.20 \\
\hline \multirow{9}{*}{$\begin{array}{l}\text { Pharmacokinetic } \\
\text { Properties }\end{array}$} & GI absorption & High & High & High & High \\
\hline & BBB permeable & Yes & Yes & Yes & Yes \\
\hline & P-gp substrate & Yes & Yes & No & No \\
\hline & $\begin{array}{l}\text { CYP1A2 } \\
\text { inhibitor }\end{array}$ & Yes & No & No & Yes \\
\hline & $\begin{array}{l}\text { CYP2C19 } \\
\text { inhibitor }\end{array}$ & Yes & Yes & Yes & Yes \\
\hline & $\begin{array}{l}\text { CYP2C9 } \\
\text { inhibitor }\end{array}$ & No & No & No & Yes \\
\hline & $\begin{array}{l}\text { CYP2D6 } \\
\text { Inhibitor }\end{array}$ & No & No & No & No \\
\hline & $\begin{array}{l}\text { CYP3A4 } \\
\text { inhibitor }\end{array}$ & No & No & No & Yes \\
\hline & $\begin{array}{l}\text { Log Kp (Skin } \\
\text { permeation) }\end{array}$ & $-4.62 \mathrm{~cm} / \mathrm{s}$ & $-6.14 \mathrm{~cm} / \mathrm{s}$ & $-5.79 \mathrm{~cm} / \mathrm{s}$ & $-5.99 \mathrm{~cm} / \mathrm{s}$ \\
\hline \multirow{5}{*}{$\begin{array}{l}\text { Medicinal Chemistry } \\
\text { Properties }\end{array}$} & Lipinski & Yes & Yes & Yes & Yes \\
\hline & Ghose & Yes & Yes & Yes & Yes \\
\hline & $\begin{array}{l}\text { Bioavailability } \\
\text { Score }\end{array}$ & 0.55 & 0.55 & 0.55 & 0.55 \\
\hline & Lead-likeness & $\begin{array}{c}\text { No, } 2 \\
\text { Violations }\end{array}$ & No, 1 violation & Yes & Yes \\
\hline & $\begin{array}{l}\text { Synthetic } \\
\text { accessibility }\end{array}$ & 2.75 & 4.32 & 4.72 & 3.77 \\
\hline \multirow{7}{*}{$\begin{array}{l}\text { Toxicoinformatic } \\
\text { Properties }\end{array}$} & Toxicity Class & 5 & 4 & 5 & 5 \\
\hline & Mutagenic & None & None & None & None \\
\hline & Tumorigenic & None & None & None & None \\
\hline & Irritant & None & None & High & None \\
\hline & $\begin{array}{l}\text { Reproductive } \\
\text { effects }\end{array}$ & None & None & None & None \\
\hline & $\begin{array}{l}\text { Possible Toxic } \\
\text { Target }\end{array}$ & None & None & None & $\begin{array}{c}\text { Amine oxidase } \\
\text { prostaglandin } G / H \\
\text { synthase } 1\end{array}$ \\
\hline & $\begin{array}{c}\text { Toxic } \\
\text { Fragments }\end{array}$ & None & None & None & None \\
\hline
\end{tabular}

* Theoretical values. Abbreviations: GI-Gastrointestinal absorption; BBB-Blood brain barrier; P-gp-Glycoprotein P; GPCR - Receptor of protein G; MW-Molecular weight; RB-Rotatable bonds; BD—Number of H donors; BA-Number of H-bond acceptors; TPSA-Total polar surface area.

Because cacalol showed interesting physicochemical, pharmacokinetic and toxicoinformatic properties among all analyzed cacalolides, we next attempted to indentify its most important biological targets through the use of an in silico approach. We found that some molecules involved in the regulation of the immune system could potentially interact with cacalol including: Fc epsilon receptor, MAPK signaling, PI3K-AKT pathway and nerve growth factor (Table 2). 
Table 2. Enrichment analysis (GO and Pathway) of the main 50 targets that interact with cacalol using network pharmacology approaches *.

\begin{tabular}{ccccc}
\hline Compound & Pathway or GO Term & Count & $p$-Value & Data Base \\
\hline & $\begin{array}{c}\text { Innate immune system } \\
\text { (hsa-168249) } \\
\text { Cacalol }\end{array}$ & 24 & $2.43 \times 10^{-20}$ & Reactome \\
& $\begin{array}{c}\text { VEGFA-VEGFR2 pathway } \\
\text { (hsa-4420097) } \\
\text { Fc epsilon receptor } \\
\text { signaling (hsa-2454202) } \\
\quad \begin{array}{c}\text { PI3K-Akt pathway } \\
\text { (hsa04151) }\end{array}\end{array}$ & 12 & $4.42 \times 10^{-12}$ & Reactome \\
& $\begin{array}{c}\text { MAPK signaling pathway } \\
\text { (hsa04010) }\end{array}$ & 12 & $4.42 \times 10^{-12}$ & Reactome \\
& $\begin{array}{c}\text { Protein kinase activity } \\
\text { (GO:0004672) }\end{array}$ & 26 & $12.58 \times 10^{-12}$ & KEGG $^{1}$ \\
\hline
\end{tabular}

* Theoretical values. ${ }^{1}$ Kyoto Encyclopedia of genes and genomes. ${ }^{2}$ Gene Ontology-Molecular Function.

\subsection{Experimental Validation of Anti-Inflammatory/Anti-Allergic Activity}

To validate the anti-inflammatory/anti-allergic properties of cacalol that were predicted by bioinformatic analysis, we performed in vitro pharmacological assays using a very well established IgE/Antigen-dependent degranulation cellular model in bone marrow-derived mast cells (BMMCs).

\subsubsection{Cacalolides Inhibit Mast Cell Degranulation Activated by FceRI Triggering In Vitro}

In order to validate the potential inhibitory activity of tested cacalolides, their effect on FceRI-dependent activation of BMMCs was evaluated, taking advantage of this cellular model that has been widely utilized to determine the potential anti-inflammatory activity of a number of natural and synthetic compounds $[4,5]$.

Among the four compounds evaluated, cacalol showed the highest inhibitory activity on IgE/Antigen-dependent degranulation. Cacalol, at $30 \mu \mathrm{M}$, produced an $88 \%$ inhibition of degranulation, followed by maturine acetate and cacalol acetate which, at $100 \mu \mathrm{M}$ concentrarion, caused an inhibition of almost $100 \%$ and $85 \%$, respectively. Finally, cacalone produced a blockage close to $100 \%$ at a concentration of $300 \mu \mathrm{M}$ (Figure 2).
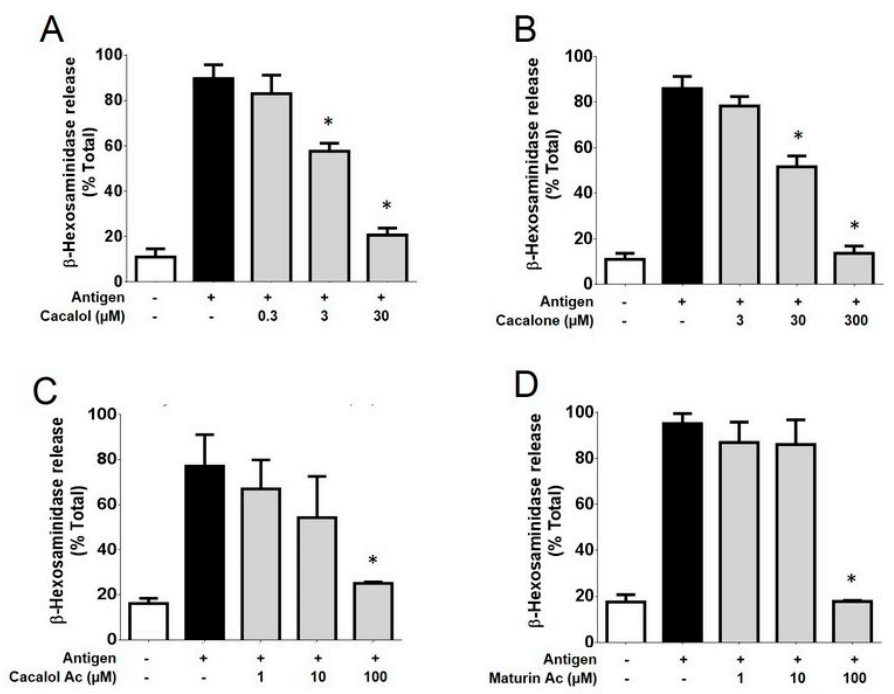

Figure 2. Cacalolides inhibit degranulation stimulated by antigen in bone marrow-derived mast cells. Effect of cacalol (A) cacalone (B) cacalol acetate (C) and maturine acetate (D) pre-treatment on DNP-HSA-induced degranulation, $n=3 .{ }^{*} p \leq 0.05$. 


\subsubsection{Cacalol Interfered with FceRI-Induced Intracellular Calcium Mobilization}

Cacalol caused a $40 \%$ inhibition of the intracellular calcium $\left[\mathrm{Ca}^{2+}\right] i$ mobilization required for IgE/antigen-induced degranulation at concentrations between 0.3 and $3 \mu \mathrm{M}$, while at $30 \mu \mathrm{M}$ it almost completely inhibited $\left[\mathrm{Ca}^{2+}\right]$ i mobilization in bone marrow-derived mast cells (Figure 3).
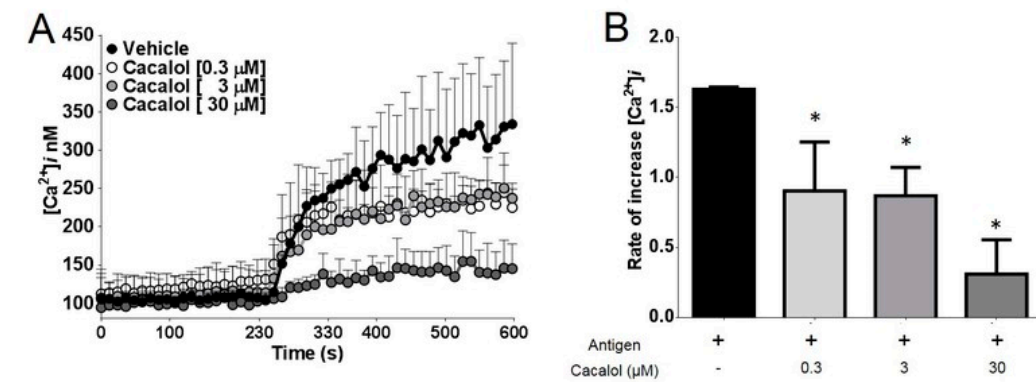

\begin{tabular}{|c|c|c|}
\hline Treatment & Rate of increase $\left[\mathrm{Ca}^{2+}\right]$ & Max $\left[\mathrm{Ca}^{2+}\right] i$ \\
\hline Vehicle & $1.630 \pm 0.016$ & $334.2 \pm 105.7$ \\
\hline Cacalol $[0.3 \mu \mathrm{M}]$ & $0.903 \pm 0.350^{*}$ & $225.3 \pm 24.24$ \\
\hline Cacalol $[3 \mu \mathrm{M}]$ & $0.869 \pm 0.202^{*}$ & $237.4 \pm 19.81$ \\
\hline Cacalol $[30 \mu \mathrm{M}]$ & $0.309 \pm 0.245^{*}$ & $144.0 \pm 19.57^{*}$ \\
\hline
\end{tabular}

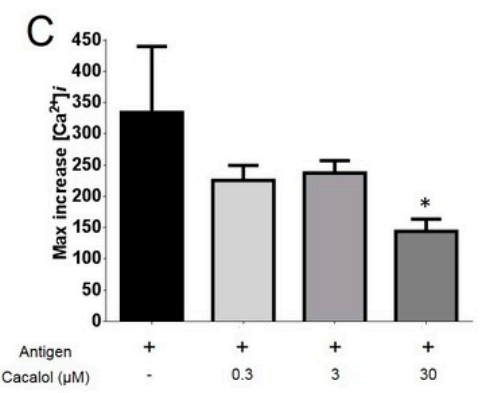

Figure 3. Cacalol inhibits intracellular calcium influx stimulated by FceRI receptor in bone marrow-derived mast cells. (A) Representative trace of intracellular calcium rise in cells pre-treated with either vehicle or different concentrations of cacalol; (B) Rate of increase of $\left[\mathrm{Ca}^{2+}\right] i$; (C) Maximum concentration of $\left[\mathrm{Ca}^{2+}\right] i . n=3 .{ }^{*} p \leq 0.05$.

\subsubsection{Cacalol Interferes with ROS Production Induced by IgE/Ag Complexes}

Cacalol at concentrations between 30 and $300 \mu \mathrm{M}$ almost completely inhibited the production of ROS in bone marrow-derived mast cells challenged with IgE/Ag complexes, compared to the reference antioxidant Trolox (5 mM) (Figure 4).

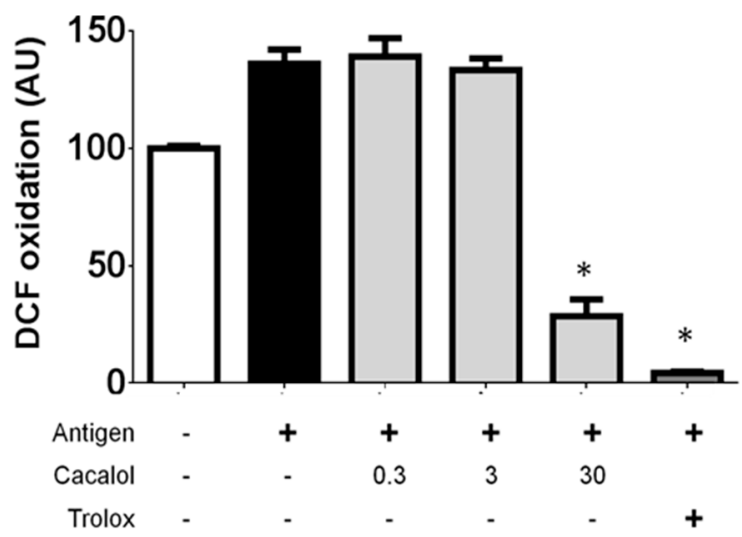

Figure 4. Cacalol inhibits FceRI-triggered degranulation in BMMCs as the antioxidant Trolox does.

* $p \leq 0.05$. 


\section{Discussion}

Natural products have proven to be a rich source in the search and development of new drugs, either used directly or as inspiring molecules in drug development. Many of them are already in use for treatment of several diseases all over the world [16].

In the present study, we have used computational tools to perform a preliminary examination of the main pharmacokinetic, medicinal chemistry and toxicoinformatic properties of selected cacalolides in order to further assess their therapeutic potential. The use of computer-aided drug discovery tools has been shown to save time and resources, and to facilitate the drug discovery process [17]. First at all, none of the four compounds examined in this study yielded any toxicity parameter derived from the chemoinformatic analysis. There are no toxicological studies reported previously for these cacalolides, except for a recent in vitro study demonstrating that cacalol from Cacalia delphiniifolia (an Asian herbal plant) failed to induce apoptosis in human mammary epithelial cells. In contrast, this cacalolide induced apoptosis in breast cancer cells and displayed cytotoxic effects in this cellular model [18].

Our analysis also revealed that the compounds directly interacted with signaling pathways associated with the immune system including the FceRI receptor pathway, the VEGF receptor (VEGFR2), and intracellular targets such as the activation of the PI3K-Akt kinases of the MAPKs kinases and the activation of other non-specific protein kinases.

In vitro results on FcERI dependend-degranulation of mast cells indicate that cacalol had a higher activity than other similar sesquiterpene compounds tested. This is probably due to its unstable chemical structure, which may allow for quick decomposition into other more stable compounds by assimilating electrons derived from ROS [19] produced by FceRI activation. The activation of membrane calcium channels linked to the Stored Operated Calcium Entry (SOCE) in mast cells may need the activation of Fc-receptors in multiple cell types of the immune system [20,21]. Interestingly, cacalol acetate, a more stable derivative generated by synthetic chemical acetylation of cacalol, is showed less inhibitory activity in the mast cells degranulation assay. In the same way, maturin acetate, a naturally occurring compound of "matarique" (P. peltatum), also stable under our experimental conditions, displayed an activity similar to that of cacalol acetate. This low activity was probably due to the fact that the acetyl group in both compounds conferred more stability to these molecules, which prevents them from accepting unpaired electrons from ROS [14,22]. Finally, although cacalone has been described as a more potent anti-oxidant and anti-inflammatory compound than even cacalol in the in vivo model of skin inflammation induced by TPA [12], this compound displayed poor anti-inflammatory activity in mast cells. These contrasting results are probably explained by the fact that the two models evaluated the inflammation produced by different immune cells and that cacalone was a 1:1 mixture with its putatively inactive epicacalone isomer [23]. Nevertheless, cacalol is not the only sesquiterpene possessing good inhibitory activity in the mast cell degranulation assay triggered by the Fc\&RI receptor. Other sesquiterpenes reported in the literature such as parthenolide, also inhibits the degranulation of mast cells by reducing the activation of $\mathrm{NFKB}$ and Fyn-dependent microtubule formation [24]. Additional sesquiterpenes possessing inhibitory activity similar to cacalol include deacetyleupaserrin, (3S,6R,7R,8R)-3-hydroxy-8-acetoxy-sarracenyloxygermacra-1(10),4,11(13)-trien-6,12-olide, (3S,6R,7R,8R)3-hydroxy-8-(2'-methyl-butyroyloxy)-14-oxomelampa-1(10), 4-dien-6,12-olide and eupaformosanin, are mechanistically associated to the inhibition of p38 and Akt phosphorylation as well as to the partial inhibition of intracellular calcium mobilization $\left(\left[\mathrm{Ca}^{2+}\right] i\right)[25]$.

\section{Materials and Methods}

\subsection{Reagents}

All organic solvents were purchased from J.T. Baker (Radnor, PA, USA). 2'7'-dichlorofluorescein diacetate (DCF-DA), dinitrophenyl-human seric albumin (DNP-HSA), igepal, and indomethacin were obtained from Sigma-Aldrich (St. Louis, MO, USA). The antioxidant Trolox was from Calbiochem 
(San Diego, CA, USA), FURA-2AM from Thermo Fisher Scientific (Waltham, MA, USA). Finally, cacalol, cacalone and maturin acetate was purified as described below.

\subsection{Isolation and Purification of Cacalolides}

Cacalol and cacalone were isolated and purified from P. decompositum roots as previously described [26]. Cacalol acetate: acetylation of cacalol to obtain cacalol acetate was carried out as previously reported [27]. Maturin acetate was purified as described [13]. The compounds' identities were corroborated by their ${ }^{1} \mathrm{H}-\mathrm{NMR}$ or ${ }^{13} \mathrm{C}-\mathrm{NMR}$ spectral data (see the Supplementary) obtained on a Bruker Avance III $300 \mathrm{MHz}$ (Cambridge Isotope, Tewksbury, MA, USA), or High Performance Liquid Chromatography (HPLC) performed an Agilent 1200 Series Binary SL (Agilent; Santa Clara, CA, USA) using a Eclipse Plus C18, $2.1 \times 100$ mm, 3.5 $\mu$ m (Agilent; Santa Clara, CA, USA), Detector: Waters 2996 UV-Vis Photo Diode Array (Waters, Mildford, MA, USA) or Gas Chromatography coupled to Mass Spectrometry (GC-MS) was performed with a JEOL GCmate (Peabody, MA, USA) were compared with those reported in the literature, establishing that four compounds were in fact cacalol, cacalol acetate, cacalone and maturin acetate.

\subsection{Chemical Characterization}

Cacalol: ${ }^{1} \mathrm{H}-\mathrm{NMR}\left(300 \mathrm{MHz}, \mathrm{CHCl}_{3}, \delta \mathrm{ppm}\right) 7.24-7.22(\mathrm{~m}, 1 \mathrm{H}), 4.78(\mathrm{~s}, 1 \mathrm{H}), 3.24-3.01(\mathrm{~m}, 1 \mathrm{H})$, $2.98(\mathrm{dd}, J=17.3,4.9 \mathrm{~Hz}, 1 \mathrm{H}), 2.60(\mathrm{~m}, 1 \mathrm{H}), 2.53(\mathrm{~s}, 3 \mathrm{H}), 2.38(\mathrm{~d}, 3 \mathrm{H}), 1.95-1.72(\mathrm{~m}, 4 \mathrm{H}), 1.20-1.19(\mathrm{~d}$, $J=7.0 \mathrm{~Hz}, 3 \mathrm{H}$ ); GC-MS shown peak with purity $93 \%$ at $23.9 \mathrm{~min}$, this peak corresponded according to MS with the molecular weight of cacalol EI + MS $m / z 230\left(\mathrm{M}^{+}, 58\right), 215(100)$ coinciding with what was previously reported [28].

Cacalol acetate: ${ }^{1} \mathrm{H}-\mathrm{NMR}\left(300 \mathrm{MHz}, \mathrm{CHCl}_{3}, \delta \mathrm{ppm}\right) 7.24-7.23(\mathrm{~d}, 1 \mathrm{H}), 3.29-3.22(\mathrm{~m}, 1 \mathrm{H}), 2.87-2.78$ $(\mathrm{m}, 1 \mathrm{H}), 2.57(\mathrm{~s}, 3 \mathrm{H}), 2.39(\mathrm{~s}, 3 \mathrm{H}), 2.38-2.37(\mathrm{~d}, 3 \mathrm{H}), 1.94-1.76(\mathrm{~m}, 4 \mathrm{H}), 1.21-1.18(\mathrm{~d}, 3 \mathrm{H})$; and ${ }^{13} \mathrm{C}-\mathrm{NMR}$ (75 MHz, $\left(\mathrm{CHCl}_{3}, \delta\right.$ ppm) 168.65, 145.18, 141.42, 135.43, 131.42, 127.09, 126.86, 124.93, 116.74, 29.97, $28.92,23.43,21.38,20.49,16.59,14.26,11.27$.

Cacalone-epicacalone mixture (CEM): ${ }^{1} \mathrm{H}-\mathrm{NMR}\left(300 \mathrm{MHz}, \mathrm{CHCl}_{3}\right) 7.25(\mathrm{~d}, 1 \mathrm{H}), 3.10-3.06(\mathrm{~m}, 1 \mathrm{H})$, 2.87-2.84 (m, OH), 2.49-2.44 (m, 1H), 2.19-2.18 (d, 3H), 1.73-167 (m, 5H), $1.58(\mathrm{~s}, 3 \mathrm{H}), 1.29-1.27(\mathrm{~d}, 3 \mathrm{H})$; GC-MS shown two peak with purity $78.8 \%$ at 26.3 and $27 \mathrm{~min}$, these peaks corresponded according to MS to the molecular weight of cacalone and epi-cacalone isomer. EI + MS $m / z 246\left(\mathrm{M}^{+}, 45\right.$ and 60), 231 (70 and 90), 204 (20 and 40), 191 (100) coinciding with what was previously reported [23,29]. The residual peaks may represent cacalol and radulifolin $B$ based on their MS spectra.

Maturin acetate: ${ }^{1} \mathrm{H}-\mathrm{NMR}\left(300 \mathrm{MHz}, \mathrm{CHCl}_{3}, \delta \mathrm{ppm}\right) 11.01(\mathrm{~s}, 1 \mathrm{H}), 8.32-8.29(\mathrm{dd}, 1 \mathrm{H}), 7.84(\mathrm{~s}, 1 \mathrm{H})$, 7.43-7.41 (d, 2H), $5.34(\mathrm{~s}, 2 \mathrm{H}), 4.45(\mathrm{~s}, 3 \mathrm{H}), 2.80(\mathrm{~s}, 3 \mathrm{H}), 2.09(\mathrm{~s}, 3 \mathrm{H})$. HPLC shown one peak with purity $99 \%$ at $29.2 \mathrm{~min}$, according to MS this peak corresponded to the molecular weight of maturin acetate. $\mathrm{EI}+\mathrm{MS} m / z 312\left(\mathrm{M}^{+}, 100\right), 254$ (90) coinciding with what was previously reported [13].

\subsection{Chemoinformatic Analysis}

To calculate the bioinformatics properties of the compounds we used Osiris DataWarrior (DataWarrior V4.7.2, Idorsia Pharmaceuticals Ltd., Allschwil, Switzerland), it is a freeware software that calculates lipophilicity, expressed as compound $\log \mathrm{P}(\log \mathrm{P})$, solubility in water, expressed as $\log$, molecular weight, drug-likeness indices and drug score; moreover, toxicological properties of the compounds may also be shown. Osiris was used to assess the possible toxicity risks as well as the aforementioned biophysical properties of cacalol, cacalol acetate, cacalone, and maturin acetate. The description of a computational medicinal chemistry can be found in a previous report [30].

\subsection{Properties Calculated Using Molinspiration and PROTOX}

CLogP (octanol/water partition coefficient) is calculated by the methodology developed by Molinspiration as the sum of fragment-based contributions and correction factors. Molecular polar surface area (PSA), topological polar surface area (TPSA) were calculated based in the sum of 
fragmented contributions. Molecular PSA has been shown to be a very good descriptor characterizing drug absorption, including intestinal absorption, bioavailability, $\mathrm{CaCo}-2$ permeability, blood-brain barrier penetration, while rodent oral toxicity can be estimated by using the PROTOX web server. Based on toxic classes defined according to the globally harmonized system of classification for the labeling of chemicals six classes exist: Class I is fatal if swallowed ( $\mathrm{LD}_{50}<5 \mathrm{mg} / \mathrm{kg}$ ), Class II is fatal if swallowed ( $\mathrm{LD}_{50}<50 \mathrm{mg} / \mathrm{Kg}$ ), Class III toxic if swallowed $\left(\mathrm{LD}_{50}<300 \mathrm{mg} / \mathrm{Kg}\right.$ ), Class IV harmful if swallowed ( $\mathrm{LD}_{50}<2000 \mathrm{mg} / \mathrm{Kg}$ ), Class V may be harmful if swallowed $\left(\mathrm{LD}_{50}<5000 \mathrm{mg} / \mathrm{Kg}\right.$ ), Class VI non-toxic $\left(\mathrm{LD}_{50}>5000 \mathrm{mg} / \mathrm{Kg}\right.$ ). The PROTOX web server was used to perform an in silico prediction of rodent oral toxicity according to The European Parliament and Council of the European Union Regulation (REACH) [31].

\subsection{Properties Calculated Using Swiss ADME}

Swiss Bioinformatic Institute possesses a web server that calculates several ADME properties that could help to delve in the pharmaceutical properties of cacalol, cacalol acetate, cacalone, and maturin acetate in order to determine its potential to reach clinics. The complete description of the computational medicinal chemistry algorithm was published [32]. We use consensus Log P from 5 different predictions (iLOGP, XLOGP3, WLOGP, MLOGP, Silicos-IT); Log S (Silicos-IT) which is fragmental method calculated; Ghose improvement for the Lipinski rule of Five [33], and synthetic accessibility from 1 very easy to 10 very difficult, implemented in the software.

\subsection{Network Pharmacology}

Since cacalol was the most interesting compound we wanted to identify the most important biological targets and pathways that could interact with such compound through the use of a network pharmacology approach. Predictive models were used including DRAR-CPI [34] and SEA [15]. Enrichment Analysis for Targets: Analysis of network interaction related to the first 50 targets that interact with each compound was performed using Comparative Toxicogenomics Database (CTD) [35]. The main molecular function as well as the main KEGG and Reactome pathways along with related diseases was determined. The most significantly enriched terms $(p<0.05, p$-values was corrected using the Benjamini-Hochberg procedure) were listed in Table 2.

\subsection{Animals}

C57BL/6J male mice, 25-30 g of body weight, stock number 000664, were purchased from The Jackson Laboratory (Bar Harbor, ME, USA). Mice were kept in sterile conditions, under a $12 \mathrm{~h}$ dark/light cycle, with free access to water and food at the Unit for the Production of Experimental Animals Laboratory (UPEAL) from Center for Research and Advanced Studies of the National Polytechnic Institute (Cinvestav) at Mexico City. All animal procedures were approved by the Cinvestav Institutional Ethics Committee (protocol number: 074-13).

\subsection{Bone Marrow-Derived Mast Cells Isolation and Culture}

Bone marrow-derived mast cells (BMMCs) were isolated from C57BL6/J mice, as described [36]. Briefly, bone marrow was extracted from the tibias and femurs of mice and cultured in RPMI 1640 (Sigma-Aldrich, St. Louis, MO, USA) medium supplemented with IL-3 (10 ng/mL; PeproTech, Rocky Hill, NJ, USA) and 10\% FBS, $100 \mathrm{UI} / \mathrm{mL}$ penicillin, $100 \mathrm{mg} / \mathrm{mL}$ streptomycin, $50 \mathrm{mM}$ 2-ME, and 13 nonessential amino acids (Invitrogen, Carlsbad, CA, USA). Cultures were maintained for 4 weeks, and media were changed every 5-7 days. Subsequently, BMMCs differentiation was assessed by detecting the expression of the FceRI receptor in the plasma membrane (by flow cytometry) and by evaluating the release of $\beta$-hexosaminidase after IgE/Ag stimulation [37]. Only cultures that were $98 \%$ positive for FcERI receptor expression and showing a dose response of $\beta$-hexosaminidase release after IgE/ Ag addition were used in the study. For each experiment, BMMCs were sensitized with $100 \mathrm{ng} / \mathrm{mL}$ a monoclonal anti-DNP IgE (clone SPE-7; (Sigma-Aldrich, St. Louis, MO, USA) for $24 \mathrm{~h}$ at $37^{\circ} \mathrm{C}$, because 
this condition was shown to increase BMMCs' responsiveness to antigen. Routinely, after sensitization, cells were collected and resuspended in fresh culture medium or Tyrode's BSA buffer $(135 \mathrm{mM} \mathrm{NaCl}$, $5 \mathrm{mM} \mathrm{KCl}, 1 \mathrm{mM} \mathrm{MgCl} 2,1.8 \mathrm{mM} \mathrm{CaCl}_{2}, 5.6 \mathrm{mM}$ glucose, $0.5 \mathrm{~g} / \mathrm{L}$ BSA, and $20 \mathrm{mM} \mathrm{HEPES}$ pH 7.4 for calcium experiments. For the ROS production experiments, sensitized cells were washed and resuspended in Tyrode's Buffer without BSA.

\subsection{Solubilization of Cacalol, Cacalol Acetate, Cacalone and Maturin Acetate for Experiments}

For in vitro testing of the effects of cacalol, cacalol acetate, cacalone and maturine acetate on mast cells, the compound was dissolved in $0.1 \%$ DMSO which was also used as vehicle in all experiments.

\subsection{1. $\beta$-Hexosaminidase Degranulation Assay}

Two million IgE-sensitized cells were centrifuged at $500 \times g$ during $5 \mathrm{~min}$ and suspended in $1 \mathrm{~mL}$ Tyrode's/BSA buffer of the following composition: $20 \mathrm{mM}$ HEPES pH 7.4, $135 \mathrm{mM} \mathrm{NaCl}, 5 \mathrm{mM}$ $\mathrm{KCl}, 1.8 \mathrm{mM} \mathrm{CaCl}_{2}, 1 \mathrm{mM} \mathrm{MgCl}$, $5.6 \mathrm{mM}$ glucose and $0.05 \%$ bovine serum albumin. Separate groups of cells were treated with vehicle, 3, 30 or $300 \mu \mathrm{M}$ of cacalolides for $15 \mathrm{~min}$ and then stimulated with antigen (27 $\mathrm{ng} / \mathrm{mL}$ DNP-HSA) during $30 \mathrm{~min}$ at $37^{\circ} \mathrm{C}$. After this treatment, cells were placed on ice for $2 \mathrm{~min}$ and centrifuged at $12,000 \times \mathrm{g}$ for $10 \mathrm{~min}$ at $4{ }^{\circ} \mathrm{C}$. Sixty $\mu \mathrm{L}$ of supernatant or (20 $\mu \mathrm{L}$ of Triton-treated cell pellet) were placed in an ELISA plate containing $40 \mu \mathrm{L}$ of $1 \mathrm{mM}$ $p$-nitrophenyl- $N$-acetyl- $\beta$-D-glucosaminide ( $p$-NAG), and incubated for one hour at $37{ }^{\circ} \mathrm{C}$ before the addition of $120 \mu \mathrm{L}$ of "stop" solution $\left(\mathrm{Na}_{2} \mathrm{CO}_{3} 0.1 \mathrm{M} / \mathrm{Na}_{2} \mathrm{HCO}_{3} 0.1 \mathrm{M}\right)$. $\beta$-hexosaminidase release was quantified by spectrophotometry in an ELISA plate reader (Tecan Sunrise, Männedorf, Switzerland) at $405 \mathrm{~nm}$, as described [38].

\subsection{Calcium Mobilization Intracellular Determination ([Ca $\left.{ }^{2+}\right]$ i)}

Intracellular calcium concentrations $\left[\mathrm{Ca}^{2+}\right] i$ were measured in IgE-sensitized BMMCs. Briefly, cells were collected and suspended in Tyrode's / BSA buffer with $5 \mu \mathrm{M}$ Fura 2-AM for 30 min at $37^{\circ} \mathrm{C}$ to load the cells. Ten million of fura 2-AM-loaded BMMCs were suspended in 2 mL Tyrode's/BSA buffer and placed in the cuvette. We monitored the fluorescence in intervals of $1.16 \mathrm{~s}$ until we reached $400 \mathrm{~s}$ on a spectrofluorometer (Fluoromax 3 Jobin Yvon, Horiba, Fukuoka, Japan) with a wavelength of $340 \mathrm{~nm}$ and $380 \mathrm{~nm}$ for excitation and $510 \mathrm{~nm}$ for emission respectively. Calcium concentration was calculated using the equation $\left[\mathrm{Ca}^{2+}\right] i=\mathrm{Kd}\left[\left(\mathrm{F}-\mathrm{F}_{\min }\right) /\left(\mathrm{F}_{\max }-\mathrm{F}\right)\right]$, where $\mathrm{Kd}$ is the dissociation constant of calcium-Fura2AM (wavelength), $\mathrm{F}_{\max }$ is fluorescence maximum concentration obtained by lysis of all cells with Triton [concentration] and $F_{\min }$ is the minimum fluorescence obtained by the addition of EDTA [concentration]. F was the current fluorescence of the sample. Basal fluorescence was recorded during $100 \mathrm{~s}$ prior to challenge with DNP-HSA antigen $(27 \mathrm{ng} / \mathrm{mL})$. $\left[\mathrm{Ca}^{2+}\right] i$ was calculated with the parameters and equation described by Grynkiewicz [39]. In some experiments, we used BMMCs suspended in $\mathrm{Ca}^{2+}$-free Tyrode's/BSA buffer and then added $1.8 \mathrm{mM} \mathrm{CaCl}_{2}$ (final concentration) at $200 \mathrm{~s}$.

\subsection{ROS Production and Antioxidant Activity}

The cells were sensitized with IgE for $24 \mathrm{~h}$ prior to challenge. $2 \times 10^{6} \mathrm{BMMC} / \mathrm{mL}$ were used in $1.5 \mathrm{~mL}$ flat top Eppendorff tubes for each treatment. They were preincubated 15 min prior to stimulating the cells with cacalolides. Trolox was used as a positive control of the antioxidant activity [40,41]. Antigen challenge (27 $\mathrm{ng} / \mathrm{mL}$ of DNP-HSA) was performed for $15 \mathrm{~min}$. DCF-DA [10 $\mu \mathrm{M}$ ] was added for $15 \mathrm{~min}$ before terminating each of the stimuli, then the tubes were centrifuged at $4{ }^{\circ} \mathrm{C}$ for $5 \mathrm{~min}$, the supernatant was removed and $300 \mu \mathrm{L}$ of igepal $0.1 \%$ at $37{ }^{\circ} \mathrm{C}$, was added by vigorous pipetting to break the cell button. The tubes were then centrifuged for 5 min at $4{ }^{\circ} \mathrm{C}$ and $200 \mu \mathrm{L}$ were placed in a 96-well plate and read at a wavelength of $488 \mathrm{~nm}$ and $565 \mathrm{~nm}$ for excitation and emission in a model FLx800 luminometer (Biotek, Winooski, VT, USA) for $1 \mathrm{~h}$, taking readings every $15 \min$ [42]. 


\subsection{Statistical Analysis}

All data were represented as percentage mean + / - standard error of the mean using the GraphPad Prism ${ }^{\circledR}$ software version 6 (GraphPad Software; La Jolla, CA, USA). Statistical analysis was performed through one way analysis of variance (ANOVA) followed by Dunnett test to compare several groups with a control. Additionally analysis with Student's t-test and Kolmogorov-Smirnoff's test were performed. Values of $p \leq 0.05$ were considered statistically significant.

\section{Conclusions}

In this work we confirmed that bioinformatics tools are useful to corroborate the validity of ethnobotanical information and also to improve decision making in the identification of compounds derived from natural products with pharmacological and pharmaceutical potential. Cacalol, a molecule possessing very specific medicinal pharmacological properties and superior to those of other similar sesquiterpenes still requires more research to ensure that it remains stable under the usual environmental conditions.

Supplementary Materials: Nuclear Magnetic Resonance (NMR) and Gas Chromatography-Mass Spectrometry (GC-MS) of cacalol, cacalol acetate, cacalone and maturine acetate.

Author Contributions: Conceptualization, J.I.C.-A., C.G.-E., R.G.-J., R.R.-C. and I.A.-C.; Data curation, J.C.G.-V., R.R.-C. and I.A.-C.; Formal analysis, J.I.C.-A., J.C.G.-V., N.A.R.-V., M.M.-C., M.J.-E., H.E.L.-V., H.M.-C., R.R.-C. and I.A.-C.; Funding acquisition, C.G.-E., R.R.-C. and I.A.-C.; Investigation, R.G.-J., R.R.-C. and I.A.-C.; Methodology, J.I.C.-A., J.C.G.-V., N.A.R.-V., M.M.-C., M.J.-E., H.E.L.-V., H.M.-C., C.G.-E. and R.G.-J.; Resources, M.M.-C., M.J.-E., H.E.L.-V., H.M.-C., C.G.-E., R.G.-J., R.R.-C. and I.A.-C.; Software, J.C.G.-V.; Supervision, C.G.-E., R.R.-C. and I.A.-C.; Writing-original draft, J.I.C.-A. and J.C.G.-V.; Writing-review \& editing, H.E.L.-V., H.M.-C., C.G.-E., R.G.-J., R.R.-C. and I.A.-C.

Funding: This research was funded in part by National Council of Science and Technology from Mexico, grant number: [FOSISS-262444] to I.A.-C.; grant number: [Conacyt-ANR-188565] and [Conacyt-FC1122] to C.G.-E.; and by Secretariat of Science, Technology and Innovation of Mexico City, grant number: [INGER-DI-CRECITES-002-2018] to I.A.-C.

Acknowledgments: The authors thank to Alfredo Ibarra Sánchez from Cinvestav for his expert technical assistance in the preparation of mast cells.

Conflicts of Interest: The authors declare no conflict of interest.

\section{References}

1. Mukai, K.; Tsai, M.; Saito, H.; Galli, S.J. Mast cells as sources of cytokines, chemokines and growth factors. Immunol. Rev. 2018, 282, 121-150. [CrossRef] [PubMed]

2. Beghdadi, W.; Madjene, L.C.; Benhamou, M.; Charles, N.; Gautier, G.; Launay, P.; Blank, U. Mast cells as cellular sensors in inflammation and immunity. Front. Immunol. 2011, 2, 1-15. [CrossRef] [PubMed]

3. Blank, U.; Madera-Salcedo, I.K.; Danelli, L.; Claver, J.; Tiwari, N.; Sánchez-Miranda, E.; Vázquez-Victorio, G.; Ramírez-Valadez, K.A.; Macias-Silva, M.; González-Espinosa, C. Vesicular trafficking and signaling for cytokine and chemokine secretion in mast cells. Front. Immunol. 2014, 5, 1-18. [CrossRef] [PubMed]

4. Singh, J.; Shah, R.; Singh, D. Targeting mast cells: Uncovering prolific therapeutic role in myriad diseases. Int. Immunopharmacol. 2016, 40, 362-384. [CrossRef]

5. Zhang, T.; Finn, D.F.; Barlow, J.W.; Walsh, J.J. Mast cell stabilisers. Eur. J. Pharmacol. 2016, 778, $158-168$. [CrossRef] [PubMed]

6. Castillo-Arellano, J.I.; Guzmán-Gutiérrez, S.L.; Ibarra-Sánchez, A.; Hernández-Ortega, S.; Nieto-Camacho, A.; Medina-Campos, O.N.; Pedraza-Chaverri, J.; Reyes-Chilpa, R.; González-Espinosa, C. Jacareubin inhibits FceRI-induced extracellular calcium entry and production of reactive oxygen species required for anaphylactic degranulation of mast cells. Biochem. Pharmacol. 2018, 154, 344-356. [CrossRef]

7. Alarcón-Aguilar, F.J.; Roman-Ramos, R.; Jimenez-Estrada, M.; Reyes-Chilpa, R.; Gonzalez-Paredes, B.; Flores-Saenz, J.L. Effects of three Mexican medicinal plants (Asteraceae) on blood glucose levels in healthy mice and rabbits. J. Ethnopharmacol. 1997, 55, 171-177. [CrossRef] 
8. Alarcón-Aguilar, F.J.; Jimenez-Estrada, M.; Reyes-Chilpa, R.; Gonzalez-Paredes, B.; Contreras, C.C.; Roman-Ramos, R. Hypoglycemic activity of root water decoction, sesquiterpenoids, and one polysaccharide fraction from Psacalium decompositum in mice. J. Ethnopharmacol. 2000, 69, 207-215. [CrossRef]

9. Romo de Vivar, A.; Pérez-Castorena, A.L.; Arciniegas, A.; Villaseñor, J.L. Secondary metabolites from Mexican species of the tribe Senecioneae (Asteraceae). J. Mex. Chem. Soc. 2007, 51, 160-172.

10. Jimenez-Estrada, M.; Merino-Aguilar, H.; Lopez-Fernandez, A.; Rojano-Vilchis, N.A.; Roman-Ramos, R.; Alarcon-Aguilar, F.J. Chemical characterization and evaluation of the hypoglycemic effect of fructooligosaccharides from Psacalium decompositum. J. Complement. Integr. Med. 2011, 8, 1413-1423. [CrossRef]

11. Merino-Aguilar, H.; Arrieta-Baez, D.; Jiménez-Estrada, M.; Magos-Guerrero, G.; Hernández-Bautista, R.J.; del Susunaga-Notario, A.C.; Almanza-Pérez, J.C.; Blancas-Flores, G.; Román-Ramos, R.; Alarcón-Aguilar, F.J. Effect of fructooligosaccharides fraction from Psacalium decompositum on inflammation and dyslipidemia in rats with fructose-induced obesity. Nutrients 2014, 6, 591-604. [CrossRef] [PubMed]

12. Jimenez-Estrada, M.; Chilpa, R.R.; Apan, T.R.; Lledias, F.; Hansberg, W.; Arrieta, D.; Aguilar, F.A. Anti-inflammatory activity of cacalol and cacalone sesquiterpenes isolated from Psacalium decompositum. J. Ethnopharmacol. 2006, 105, 34-38. [CrossRef] [PubMed]

13. Rojano-Vilchis, N.A.; Jimenez-Estrada, M.; Nieto-Camacho, A.; Torres-Avilez, A.; Bye, R.A.; Chavez-Avila, V.M.; Canales-Martinez, M.; Martinez-Elizalde, K.S.; Rodriguez-Monroy, M.A. Isolation and anti-inflammatory effects of maturin acetate from the roots of Psacalium peltatum (Asteraceae). J. Med. Plants Res. 2013, 7, 1600-1607. [CrossRef]

14. Del Carmen Juárez-Vázquez, M.; Alonso-Castro, A.J.; Rojano-Vilchis, N.; Jiménez-Estrada, M.; García-Carrancá, A. Maturin acetate from Psacalium peltatum (Kunth) Cass. (Asteraceae) induces immunostimulatory effects in vitro and in vivo. Toxicol. In Vitro 2013, 27, 1001-1006. [CrossRef]

15. Wang, Z.; Liang, L.; Yin, Z.; Lin, J. Improving chemical similarity ensemble approach in target prediction. J. Cheminform. 2016, 8, 2-10. [CrossRef] [PubMed]

16. Chin, Y.W.; Balunas, M.J.; Chai, H.B.; Kinghorn, A.D. Drug discovery from natural sources. AAPS J. 2006, 8 , E239-E253. [CrossRef] [PubMed]

17. Leelananda, S.P.; Lindert, S. Computational methods in drug discovery. Beilstein. J. Org. Chem. 2016, 12, 2694-2718. [CrossRef] [PubMed]

18. Liu, W.; Furuta, E.; Shindo, K.; Watabe, M.; Xing, F.; Pandey, P.R.; Mo, Y.Y. Cacalol, a natural sesquiterpene, induces apoptosis in breast cancer cells by modulating Akt-SREBP-FAS signaling pathway. Breast Cancer. Res. Treat. 2011, 128, 57-68. [CrossRef] [PubMed]

19. Jiménez-Estrada, M.; Reyes-Chilpa, R.; Navarro-Ocaña, A.; Baez, D.A. Reactivity of several reactive oxygen species (ROS) with the sesquiterpene cacalol. Nat. Prod. Comm. 2008, 3, 479-482.

20. Feske, S. ORAI1 and STIM1 deficiency in human and mice: Roles of store-operated $\mathrm{Ca}^{2+}$ entry in the immune system and beyond. Immunol. Rev. 2009, 231, 189-209. [CrossRef]

21. Saul, S.; Gibhardt, C.S.; Schmidt, B.; Lis, A.; Pasieka, B.; Conrad, D.; Jung, P.; Gaupp, R.; Wonnenberg, B.; Diler, E.; et al. A calcium-redox feedback loop controls human monocyte immune responses: The role of ORAICa $^{2+}$ channels. Sci. Signal. 2016, 9, ra26. [CrossRef] [PubMed]

22. Gómez-Vidales, V.; Granados-Oliveros, G.; Nieto-Camacho, A.; Reyes-Solís, M.; Jiménez-Estrada, M. Cacalol and cacalol acetate as photoproducers of singlet oxygen and as free radical scavengers, evaluated by EPR spectroscopy and TBARS. RSC Adv. 2014, 4, 1371-1377. [CrossRef]

23. Inman, W.D.; Luo, J.; Jolad, S.D.; King, S.R.; Cooper, R. Antihyperglycemic sesquiterpenes from Psacalium decompositum. J. Nat. Prod. 1999, 62, 1088-1092. [CrossRef] [PubMed]

24. Miyata, N.; Gon, Y.; Nunomura, S.; Endo, D.; Yamashita, K.; Matsumoto, K.; Hashimoto, S.; Ra, C. Inhibitory effects of parthenolide on antigeninduced microtubule formation and degranulation in mast cells. Int. Immunopharmacol. 2008, 8, 874-880. [CrossRef] [PubMed]

25. Itoh, T.; Oyama, M.; Takimoto, N.; Kato, C.; Nozawa, Y.; Akao, Y.; Iinuma, M. Inhibitory effects of sesquiterpene lactones isolated from Eupatorium chinense L. on IgE-mediated degranulation in rat basophilic leukemia RBL-2H3 cells and passive cutaneous anaphylaxis reaction in mice. Bioorg. Med. Chem. 2009, 17, 3189-3197. [CrossRef] [PubMed] 
26. Campos, M.G.; Oropeza, M.; Torres-Sosa, C.; Jimenez-Estrada, M.; Reyes-Chilpa, R. Sesquiterpenoids from antidiabetic Psacalium decompositum block ATP sensitive potassium channels. J. Ethnopharmacol. 2009, 123, 489-493. [CrossRef] [PubMed]

27. Anaya, A.L.; Hernández-Bautista, B.E.; Torres-Barragán, A.; León-Cantero, J.; Jiménez-Estrada, M. Phytotoxicity of cacalol and some derivatives obtained from the roots of Psacalium decompositum (A. Gray) $\mathrm{H}$. Rob. \& Brettell (Asteraceae), matarique or maturin. J. Chem. Ecol. 1996, 22, 393-403. [CrossRef] [PubMed]

28. Kedrowski, B.L.; Hoppe, R.W. A concise synthesis of (+/-)-cacalol. J. Org. Chem. 2008, 73, 5177-5179. [CrossRef] [PubMed]

29. Yuste, F.; Diaz, E.; Walls, F.; Jankowski, K. The structure of cacalone. J. Org. Chem. 1976, 41, 4103-4106. [CrossRef]

30. Sander, T.; Freyss, J.; von Korff, M.; Rufener, C. DataWarrior: An open-source program for chemistry aware data visualization and analysis. J. Chem. Inf. Model. 2015, 55, 460-473. [CrossRef] [PubMed]

31. Drwal, M.N.; Banerjee, P.; Dunkel, M.; Wettig, M.R.; Preissner, R. ProTox: A web server for the in silico prediction of rodent oral toxicity. Nucl. Acids Res. 2014, 42, W53-W58. [CrossRef] [PubMed]

32. Daina, A.; Zoete, V. A Boiled-egg to predict gastrointestinal absorption and brain penetration of small molecules. Chem. Med. Chem. 2016, 11, 1117-1121. [CrossRef] [PubMed]

33. Ghose, A.K.; Viswanadhan, V.N.; Wendoloski, J.J. A knowledge-based approach in designing combinatorial or medicinal chemistry libraries for drug discovery. 1. A qualitative and quantitative characterization of known drug databases. J. Comb. Chem. 1999, 1, 55-68. [CrossRef] [PubMed]

34. Luo, H.; Chen, J.; Shi, L.; Mikailov, M.; Zhu, H.; Wang, K.; He, L.; Yang, L. DRAR-CPI: A server for identifying drug repositioning potential and adverse drug reactions via the chemical protein interactome. Nucl. Acids Res. 2011, 39, W492-W498. [CrossRef]

35. Mattingly, C.J.; Colby, G.T.; Forrest, J.N.; Boyer, J.L. The Comparative toxicogenomics database (CTD). Environ. Health Perspect. 2003, 111, 793-795. [CrossRef]

36. Madera-Salcedo, I.K.; Cruz, S.L.; Gonzalez-Espinosa, C. Morphine prevents lipopolysaccharide-induced TNF secretion in mast cells blocking IB kinase activation and SNAP-23 phosphorylation: Correlation with the formation of a $\beta$-Arrestin/TRAF6 complex. J. Immunol. 2013, 191, 3400-3409. [CrossRef]

37. Manetz, T.S.; Gonzalez-Espinosa, C.; Arudchandran, R.; Xirasagar, S.; Tybulewicz, V.; Rivera, J. Vav1 regulates phospholipase cgamma activation and calcium responses in mast cells. Mol. Cell. Biol. 2001, 21, 3763-3774. [CrossRef] [PubMed]

38. Saitoh, S.; Arudchandran, R.; Manetz, T.S.; Zhang, W.; Sommers, C.L.; Love, P.E.; Rivera, J.; Samelson, L.E. LAT is essential for Fc(epsilon)RI-mediated mast cell activation. Immunity 2000, 12, 525-535. [CrossRef]

39. Grynkiewicz, G.; Poenie, M.; Tsien, R.Y. A new generation of $\mathrm{Ca}^{2+}$ indicators with greatly improved fluorescence properties. J. Biol. Chem. 1985, 260, 3440-3450.

40. Davies, M.J.; Forni, L.G.; Willson, R.L. Vitamin E analogue Trolox CEsr and pulse-radiolysis studies of free-radical reactions. Biochem. J. 1988, 255, 513-522.

41. Bentayeb, K.; Rubio, C.; Nerín, C. Study of the antioxidant mechanisms of Trolox and eugenol with 2,2'-azobis (2-amidinepropane) dihydrochloride using ultra-high performance liquid chromatography coupled with tandem mass spectrometry. Analyst 2012, 137, 459-470. [CrossRef] [PubMed]

42. Itoh, T.; Tsukane, M.; Koike, M.; Nakamura, C.; Ohguchi, K.; Ito, M.; Akao, Y.; Koshimizu, S.; Nozawa, Y.; Wakimoto, T.; et al. Inhibitory effects of whisky congeners on IgEmediated degranulation in rat basophilic leukemiaRBL2H3 cells and passive cutaneous anaphylaxis reaction in mice. J. Agric. Food. Chem. 2010, 58, 7149-7157. [CrossRef] [PubMed]

Sample Availability: Samples of the compounds are available from the authors. 